\section{Purulent fibrous and necrotizing ileitis secondary to intussusception associated with infection by Giardia intestinalis and Cystoisospora felis in a cat - case report}

\author{
Ileítefibrino purulenta e necrosante secundária a \\ intussuscepção associada a infecção por Giardia intestinalis e \\ Cystoisospora felis em gato - relato de caso
}

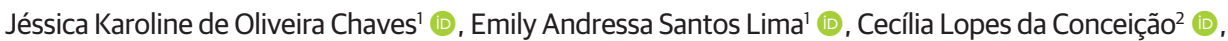
Debora Azevedo Borges ${ }^{2}$ (1) , Diefrey Ribeiro Campos ${ }^{3 *}$ (D), Fabio Barbour Scott ${ }^{4}$ (1)

'Veterinarian. Programa de Pós-graduação em Ciências Veterinárias - PPGCV, Universidade Federal Rural do Rio de Janeiro UFRRJ, Seropédica, RJ, Brasil

Veterinarian, MSc. Programa de Pós-graduação em Ciências Veterinárias - PPGCV, Universidade Federal Rural do Rio de Janeiro - UFRRJ, Seropédica, RJ, Brasil

${ }^{3}$ Veterinarian, Dr. - Post doctorate. Programa de Pós-graduação em Ciências Veterinárias - PPGCV, Universidade Federal Rural do Rio de Janeiro - UFRRJ, Seropédica, RJ, Brasil

${ }^{4}$ Veterinarian, Dr. Departamento de Parasitologia Animal, Instituto de Veteriária, Universidade Federal Rural do Rio de Janeiro - UFRRJ, Seropédica, RJ, Brasil
\end{abstract}

\begin{abstract}
Intussusception is the prolapse of an intestinal segment in the lumen of the adjacent intestinal loop. Although usually idiopathic, one of the predisposing factors is intestinal parasitism. The aim of this report is to describe the unusual case of ileo-ileal intussusception in a kitten co-parasitized by Cystoisospora felis and $G$. intestinalis A three-month-old mixed breed cat was treated after suffering from intermittent vomiting, prostration, progressive weight loss, abdominal discomfort, and diarrhea for two days. The presence of numerous Giardia intestinalis cysts and $C$. felis oocysts was detected in feces samples. The therapeutic protocol did not produce the expected result, and the patient evolved to hypovolemic shock and perished. During emergency care, it was possible to detect a palpable cylindrical abdominal mass in the caudal region of the abdomen. At necropsy, necrotizing purulent fibrinous ileitis secondary to intussusception was observed. Intestinal hyper-peristalsis associated with intense parasitism by these protozoa suggested the participation of these parasites in the genesis of the disease. Early diagnosis of infection by these parasites is vital to improve patient life quality and the accuracy of intussusception prognosis due to intestinal disorders caused by parasitism.
\end{abstract}

Keywords: giardiasis, cystoisosporiasis, feline.

\section{Resumo}

Intussuscepção é o prolapso de um segmento intestinal no lúmen da alça intestinal adjacente. Embora frequentemente idiopático, um dos fatores predisponentes inclui parasitismo intestinal. O objetivo deste relato foi descrever o caso incomum de intussuscepção ileo-ileal em um gato filhote co-parasitado por Cystoisospora felis e Giardia intestinalis. Um gato, de três meses de idade, sem raça definida, foi atendido com episódios de vômitos intermitentes, prostração, emagrecimento progressivo, desconforto abdominal e diarreia com dois dias de duração. A presença de numerosos cistos de G. intestinalis. e oocistos de C. felis foram detectados nas fezes. O protocolo terapêutico não obteve resposta desejada, o paciente evoluiu para um quadro de choque hipovolêmico e foi à óbito. Durante o atendimento emergencial, foi possível detectar uma massa abdominal palpável de formato cilíndrico na região caudal do abdômen. Na necropsia, foi observado um quadro de ileítefibrino purulenta e necrosante secundária a intussuscepção. 0 hiperperistaltismo intestinal associado ao intenso parasitismo por esses protozoários sugere a participação desses parasitos na gênese da afecção. O diagnóstico precoce dessas parasitoses é de suma importância tanto para melhorar a qualidade de vida do paciente, quanto para obter um bom prognóstico nesses casos de intussuscepção decorrente de distúrbios intestinais provocados pelo parasitismo.

Palavras-chave: giardíase, cistoisosporíase, felino.

\section{BJ $\mathrm{M}$ \\ Brazilian Journal of Veterinary Medicine}

p-ISSN 0100-2430

e-ISSN 2527-2179

อ

How to cite: Chaves, J. K. O., Lima, E. A. S., Conceição, C. L., Borges, D. A., Campos, D. R., \& Scott, F. B. (2020) Purulent fibrous and necrotizing ileitis secondary to intussus associated with infection by Giardia intestinalis and Cystoisospora felis in cat - case report. Brazilian Journal of Veterinary Medicine, 42, e107320. https://doi. org/10.29374/2527-2179.bjvm107320

Financial support. "This study was financed in part by the Coordenação de Aperfeiçoamento de Pessoal de Nível Superior - (CAPES) BrazilFinance Code 001, by Fundação de Apoio à Pesquisa Técnologica da Universidade Federal Rural do Rio de Janeiro (Fapur) - Brazil and National Council for Scientific and Technological Development - (CNPq) - Brazil.

Conflict of interests: No conflict of interests declared concerning the publication of this article.

Received: August 08, 2019

Accepted: February 27, 2020

The study was carried out at Universidade Federal Rural do Rio de Janeiro - UFRRJ, Seropédica, RJ, Brazil.

\title{
*Correspondence
}

Diefrey Ribeiro Campos

Departamento de Parasitologia Animal, Universidade Federal Rural do Rio de Janeiro - UFRRJ

Rodovia BR 465, Km 07, s/n Zona Rural, Seropédica

CEP 23890-000 - Cidade (UF), Brasil

E-mail:diefrey8@gmail.com

Copyright Chaves et al. This is an Open Access article distributed under the terms of the Creative Commons Attribution Non-Commercial License which permits unrestricted non-commercial use, distribution, and reproduction in any medium provided the original work is properly cited. 


\section{Introduction}

Intussusception is a pathology characterized by the invagination or prolapse of an intestinal segment called the intussuscept into the lumen of the adjacent portion of the intestine called the intussuscipiens (Patsikas et al., 2003; Patsikas et al., 2005; Levitt \& Bauer, 1992; Baral, 2015), resulting in reduction of the intestinal lumen and consequently total or partial obstruction of the segment, which can cause ischemia, necrosis and intestinal ruptures in serious cases (Levitt \& Bauer, 1992). This disorder can occur in any portion of the gastrointestinal tract, but in small animals like dogs and cats its appearance is usually observed in the ileocolic segment (enterocolic portion) (Patsikas et al., 2003; Patsikas et al., 2005; Levitt \& Bauer, 1992; Burkitt et al., 2009).

The clinical characteristics are very unspecific, including weight loss, dehydration (Patsikas et al. 2003), depression (Patsikas et al., 2003; Levitt \& Bauer, 1992), lethargy (Baral, 2015), anorexia, bloody diarrhea, vomiting and appearance of a palpable cylindrical abdominal mass (Baral, 2015; Levitt \& Bauer, 1992; Patsikas et al., 2003). This last clinical manifestation is the most consistent finding of intussusception in cats (Patsikas et al., 2003).

This disease can be found in dogs and cats, with greatest incidence in dogs until a year old (Patsikas et al., 2003). In cats, the Siamese and Birman breeds have the highest incidence (Baral, 2015; Burkitt et al., 2009).

The physiopathology is not yet fully elucidated. In older cats, it has been associated with neoplasms, as an alimentary lymphoma, and in some cases intestinal inflammatory disease (Baral, 2015). In young cats, its etiology is related to intestinal hypermotility disturbance, but its underlying causes are poorly defined and can be idiopathic in most cases. However, some associations with intestinal parasitism and strange linear bodies have been observed (Burkitt et al., 2009; Baral, 2015). However, some underlying causes reported in dogs have also been identified in cats, such as dietetic alterations, viral or bacterial infections in the gastrointestinal tract, previous intestinal surgery and abdominal masses (Burkitt et al., 2009; Patsikas et al., 2003; Levitt \& Bauer, 1992).

In the case of parasitosis, the protozoans $C$. felis and $G$. intestinalis are examples of parasites found in the intestinal tract of small animals. In rare situations they can cause the appearance of intussusception due to sever intestinal hyperperistalsis (Ferreira et al., 2013; Diniz et al., 2004; Tafti,1999). Protozoa of these genera are frequently found in veterinary practice, and pose a major threat to animal health by causing intestinal damage, leading to reduced nutrient absorption, weight loss, dehydration and susceptibility to secondary infections. G. intestinalis also pose a threat to human health (Ferreira et al., 2013; Tesserolli et al., 2005; Dubey, 1993). The occurrence of both protozoans is commonly associated with young animals living in crowded conditions with poor hygiene conditions (Dubey, 1993). Most infected animals remain asymptomatic, but when clinical manifestations appear, acute and/or chronic mucoid or bloody diarrhea are most commonly observed. The disease usually occurs in debilitated and/or immunosuppressed animals with concomitant gastrointestinal diseases or coinfection by other intestinal parasites. In these cases, diarrhea can be followed by dehydration, lethargy, hemorrhagic enteritis, anorexia and acute vomiting (Dubey, 1993; Tesserolli et al., 2005; Ferreira et al., 2013).

The aim of this article is to describe an uncommon case of ileo-ileal intussusception in kitten parasitized by C. felis and G. intestinalis.

\section{Clinical case}

In the county of Seropédica/Rio de Janeiro A three-month-old non-neutered mixed breed male cat was attended in the municipality of Seropédica, Rio de Janeiro state, Brazil. The cat was negative for feline leukemia virus (FeLV) and feline immunodeficiency virus (FIV). The main symptoms were prostration, progressive weight loss, abdominal discomfort, intermittent vomiting and diarrhea for two days. The animal had been adopted from the street so there was no knowledge of previous illnesses.

During the physical examination, all clinical parameters and organ systems were within normal parameters except the gastrointestinal tract, where moderate crepitus in the bowel loops and abdominal bulging were noticed. To aid in the diagnosis, complementary blood tests were performed (blood cell count and serum biochemistry) along with stool parasitology. 
The blood count indicated $720 / \mathrm{mm}^{3}$ of monocytes (reference range: 100-680/mm ${ }^{3}$ ), 225 thousand $/ \mathrm{mm}^{3}$ of platelets (reference range: $230,000-680,000 / \mathrm{mm}^{3}$ ) and $22 \%$ hematocrit (reference range: 22.0-38.0\%), showing the presence of monocytosis, mild thrombocytopenia and lower limit hematocrit for species and age, respectively. No hemoparasites were observed in the sample sent. The biochemistry tests showed some anomalies, namely $71.0 \mathrm{mg} / \mathrm{dL}$ of serum urea (reference range: 42.8-64.2 mg/dL), $15.0 \mathrm{U} / \mathrm{L}$ of alkaline phosphatase (reference range: 25.0-93.0 U/L), 1.0 U/L of gamma-glutamyl transferase (reference range: 1.3-5.1 U/L), $5.2 \mathrm{~g} / \mathrm{dL}$ of total protein (reference range: $5.4-7.8 \mathrm{~g} / \mathrm{dL}$ ), and $1.5 \mathrm{~g} / \mathrm{dL}$ of albumin (reference range: $2.1-3.3 \mathrm{~g} / \mathrm{dL}$ ). The parasitological exam of feces performed by the Faust qualitative method (Faust et al.,1938) and simple centrifugal-flotation (Sheather, 1923) showed the presence of numerous $G$. intestinalis cysts and C. felis oocysts in the stool sample.

For therapy, dietary supplementation with hypercaloric food was prescribed (Nutralife ${ }^{\circledR}$ Vetnil), along with fluid therapy with Ringer's lactate solution (50 mL, SC) in association with fenbendazole (Panacur ${ }^{\circledR} 1 \%$ - MSD Animal Health) at an oral dose of $25 \mathrm{mg} / \mathrm{kg}$ every 12 hours. toltrazuril (Baycox 5\% ${ }^{\circledR}$ - Bayer Animal Health) at an oral dose of $0.1 \mathrm{mg} / \mathrm{kg}$ every 24 hours, and benzoyl metronidazole (Brainfarma) at an oral dose of $10 \mathrm{mg} / \mathrm{kg}$ every 12 hours.

Five days after the start of treatment, the patient did not show improvement of the diarrhea and the overall condition deteriorated. During the emergency care, the presence was noted of a palpable mass in the caudal region of the abdomen, and even with intervention the cat evolved to hypovolemic shock and died. A test for qualitative and simultaneous detection of parvovirus antigens (AlereParvovirose $\mathrm{Ag}^{\circledR}$ ) was performed, with a negative result. The corpse was sent to the Pathological Anatomy Sector of Rio de Janeiro Federal Rural University (UFRRJ) for necropsy.

In the necropsy report, besides the presence of external ectoparasites, the existence of a circular lesion in the oral mucosa was described (measuring $0.4 \times 0.3 \mathrm{~cm}$ ) located near the lower canine tooth and hyperemic mucosa. The internal exam revealed the presence of pale subcutaneous tissue, approximately $2 \mathrm{~mL}$ of yellowish viscous fluid in the pericardial sac and invagination of part of the ileum and the intestinal loops of adjacent segments of the ileum itself, together with ileo-ileal intussusception (Figure 1). After correction of the intussusception, the serosa of the invaginated area (with approximate length of $13 \mathrm{~cm}$ ) was bright red, showing congestion and necrosis (Figure 2). The mucosal surface was irregular, reddish and with fibrin streaks in the central region of the lesion. The other organs did not show significant macroscopic alterations.

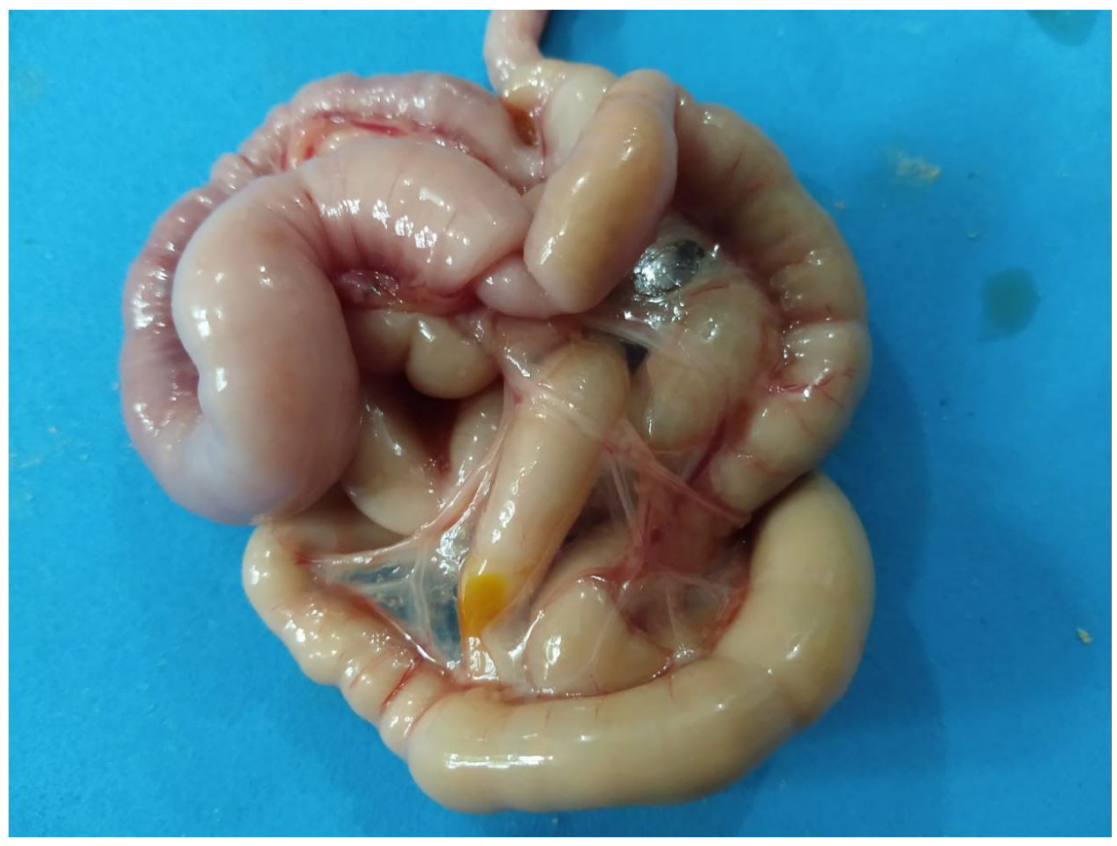

Figure 1. Macroscopic aspect of the small intestine (duodenum, jejunum and ileum) of the patient before undoing the ileal-intussusception observing the presence of invagination of part of the ileum to the intestinal loops of adjacent segments of the ileum itself. 


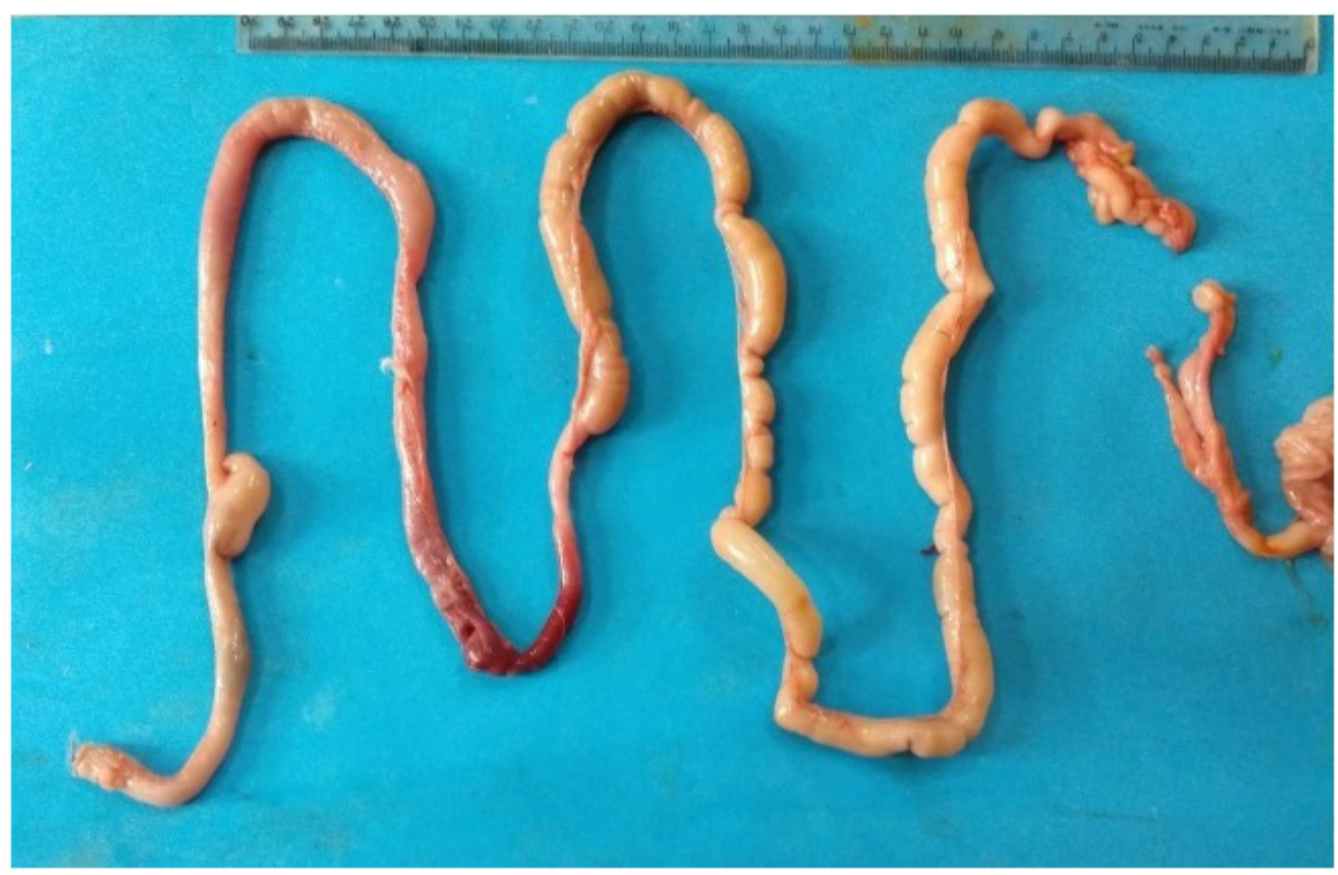

Figure 2. Macroscopic aspect of the small intestine (duodenum, jejunum and ileum) of the patient after undoing the ileo-ileum intussusception showing congestion and necrosis in the serosa of the invaginated area.

During necropsy, fragments of the ileum, kidney, spleen, liver, heart and lung were collected and sent for histopathological analysis. This revealed the presence of moderate dilation of the intestinal crypts, filled with an inflammatory cell infiltrate composed predominantly of neutrophils and histiocytes. Nuclear pyknosis of enterocytes and tissue debris (necrosis), eosinophilic fibrillary material (fibrin) with eosinophilic material (mucus), and multiple basophilic points (coccoid bacterial colonies) were also observed, accumulated and diffusely distributed among crypts and intestinal villi. A moderate amount of eosinophilic material (fibrin) in the muscle layer and serosa was also observed. In the remaining organs (kidney, spleen, liver, heart and lung), no microscopic changes were observed.

\section{Discussion}

Intussusception is a pathology that deserves greater attention among the obstructive gastrointestinal alterations in small animals. However, many authors have reported higher incidence in young animals (dogs and cats) up to one year of age (Burkitt et al., 2009; Levitt \& Bauer, 1992; Patsikas et al., 2003). Its occurrence in cats still rarely described in the literature (Burkitt et al., 2009).

The diversity of unspecific clinical signs of gastrointestinal disease frequently causes difficulties in the diagnosis and clinical care of patients, but usually the best sign is detected by abdominal palpation, revealing a firm tubular structure, present in the majority of affected cats (Baral, 2015), as observed in the present case and reported by Patsikas et al. (2003), who described it in 100\% of the evaluated animals in their study.

Despite the vulnerability of the whole alimentary tract, most cases in small animals and humans have enterocolic characteristic. Occurrence in the enteroenteric portion, as in this case, is still relatively rare (Levitt \& Bauer, 1992; Patsikas et al.,2003; Burkitt et al., 2009). Levitt \& Bauer (1992), analyzing 9 cats and 27 dogs, observed that 51\% of the animals suffered from enterocolic intussusception and 49\% enteroenteric intussusception, with restriction of the jejunum or ileum. Furthermore, the abdominal palpation in our intussusception case was also reported by those authors in $53 \%$ of the cases, corroborating other descriptions in the literature.

A series of events triggered by intestinal invagination can be used to categorize the pathology. According to Patsikas et al. (2005), an obstruction initially provokes a venous return problem, and 
consequently dilatation and congestion of the segment. In advanced stages, fibrin exudation of the serosa (responsible for intestinal adhesion) is observed, along with ischemia and necrosis of the intestinal portion in cases of permanent obstruction. All those events occurred in the present case as noted during necropsy, denoting an advanced pathological stage.

Even though most cases have idiopathic origin (Baral 2015; Levitt \& Bauer, 1992; Patsikas et al., 2003), such as double intussusception as reported by Colomé et al. (2006), Valiei \& Beheshti (2011) and Kim et al. (2012), predisposing factors can be associated with the appearance of this disease in young animals, including intestinal parasitism (Baral, 2015). In severe cases, although rare, those parasitoses can cause intense diarrhea and exacerbation of intestinal peristalsis, causing strong contractions that can cause part of the intestine to penetrate into the lumen of the adjacent intestinal segment (Diniz et al., 2004; Ferreira et al., 2013; Dubey, 1993; Tafti, 1999).

In the present study, we observed an increase of intestinal motility associated with intense parasitism by the protozoans $C$. felis and $G$. intestinalis suggesting the participation of those parasites in the genesis of the ileo-ileal intussusception. A similar case was reported by Tafti (1999), where a three-year-old Iranian sheep was diagnosed with an uncommon ileo-ileal intussusception type, associated with the presence of proliferative hyperplasic nodules of coccidiosis in the intestinal wall, as observed during necropsy. The association between pathology and the presence of intestinal parasites was also reported by Patsikas et al. (2003) in a study of four Siamese cats and three short-hair cats diagnosed with ileocolic or jejunojejunal intussusception, where four cases were related to parasitological enteritis and three to intestinal lymphoma.

The protozoans $C$. felis and $G$. intestinalis are parasites frequently found in the intestinal tract of small animals, where they can cause relevant infirmities, hence the need for early diagnosis (Tesserolli et al., 2005; Ferreira et al., 2013; Dubey, 1993). A study by Ferreira et al. (2013) in the city of Londrina, Paraná (Brazil) evaluated the frequency of gastrointestinal parasites in stool samples of dogs and cats and reported that in isolated cases the protozoan Cystoisospora spp. was most often found in the feces of small animals, followed by G. intestinalis, and in cases of coinfection, the presence of those two genera was most frequently observed. In turn, Tesserolli et al. (2005) analyzed the relative presence of gastrointestinal parasitoses in small animals in the city of Curitiba, Paraná (Brazil) and also observed a higher prevalence of the protozoan Cystoisospora spp. in the animals (dogs and cats) evaluated, followed by G. intestinalis, with high prevalence in the stool samples of dogs. This occurrence was probably associated with incorrect administration of antiparasitics the pet owners, without prescription of a veterinarian (Ferreira et al., 2013).

\section{Conclusion}

In general, ileo-ileal intussusception associated with coinfection by C. felis and G. intestinalis is an uncommon occurrence in cats. The early diagnosis of these protozoans through parasitological stool exam followed by adequate therapy is essential to increase the patient's life quality and improve prognosis of intussusception due to intestinal disorders caused by parasitism.

\section{References}

Baral, R. M. (2015). Doenças dos Intestinos. In S. E. Little (Ed.), O gato: medicina interna (pp. 620-789.) Rio de Janeiro: Roca

Burkitt, J. M., Drobatz, K. J., Saunders, H. M., \& Washabau, R. J. (2009). Signalment, history, and outcome of cats with gastrointestinal tract intussusception: 20 cases (1986-2000). Journal of the American Veterinary Medical Association, 234(6), 771-776. http://dx.doi.org/10.2460/javma.234.6.771. PMid:19284343.

Colomé, L. M., Contesini, E. A., Beck, C. A. C., Ferreira, M. P., Beheregaray, W. K., Vieira Júnior, A. R. P., \& Martins, C. G. (2006). Intussuscepção jejunoileal dupla em um cão. Acta Scientiae Veterinariae, 34(2), 225-228. http:// dx.doi.org/10.22456/1679-9216.15282.

Diniz, P. P. V. P., Sousa, M. G., Carareto, R., Furlani, J. M., Gerardi, D. G., \& Costa, M. T. (2004). Comunicação científica: aspectos da intussuscepção dupla sem obstrução do lúmen intestinal em um cão. Ciência Animal Brasileira, 5(3), 163-166. Retrieved in 2019, August 8, from https://www.redalyc.org/pdf/2890/289021868023.pdf

Dubey, J. P. (1993). Intestinal protozoa infections. The Veterinary Clinics of North America. Small Animal Practice, 23(1), 37-55. http://dx.doi.org/10.1016/S0195-5616(93)50003-7. PMid:8421888.

Faust, E. C., Tobie, J., Thomen, L. F., Sawitz, W., D’Antoni, J. S., Peres, C., Miller, M. J., Odom, V., \& Walker, J. H. (1938). A critical study of clinical laboratory technics for the diagnosis of protozoan cysts and Helminth eggs in Feces1. The American Journal of Tropical Medicine and Hygiene, 1(2), 169-183. http://dx.doi.org/10.4269/ ajtmh.1938.s1-18.169. 
Ferreira, F. P., Dias, R. C. F., Martins, T. A., Constantino, C., Pasquali, A. K. S., Vidotto, O., Freire, R. L., \& Navarro, I. T. (2013), Frequência de parasitas gastrointestinais em cães e gatos do município de Londrina, PR, com enfoque em saúde pública. Semina: Ciências Agrárias, 34(2), 3851-3858. http://dx.doi.org/10.5433/1679-0359.2013v34n6Supl2p3851.

Kim, J. M., Kang, S. S., \& Choi, S. H. (2012). Double intussusception in a Shih-Tzu puppy: the triple-circle sign. Pakistan Veterinary Journal, 32(2), 292-294.

Levitt, L., \& Bauer, M. S. (1992). Intussusception in dogs and cats: a review of 36 cases. The Canadian Veterinary Journal. La Revue Veterinaire Canadienne, 33(10), 660-664. PMid:17424091.

Patsikas, M. N., Papazoglou, L. G., Jakovljevic, S., \& Dessiris, A. K. (2005). Color Doppler ultrasonography in prediction of the reducibility of intussuscepted bowel in 15 young dogs. Veterinary Radiology \& Ultrasound, 46(4), 313-316. http://dx.doi.org/10.1111/j.1740-8261.2005.00058.x. PMid:16229432.

Patsikas, M. N., Papazoglou, L. G., Papaioannou, N. G., Savvas, I., Kazakos, G. M., \& Dessiris, A. K. (2003). Ultrasonographic findings of intestinal intussusception in seven cats. Journal of Feline Medicine and Surgery, 5(6), 335-343. http://dx.doi.org/10.1016/S1098-612X(03)00066-4. PMid:14623203.

Sheather, A. L. (1923). The detection of intestinal protozoa and mange parasites by a floatation technique. Journal of Pathology and Therapy, 36, 266-275. http://dx.doi.org/10.1016/S0368-1742(23)80052-2.

Tafti, A. K. (1999). Ileoileal intussusception associated with coccidiosis in sheep. Journal of Veterinary Medicine, Series B, 46(9), 659-663. http://dx.doi.org/10.1046/j.1439-0450.1999.00283.x. PMid:10605376.

Tesserolli, G. L., Fayzano, L., \& Agottani, J. V. B. (2005). Ocorrência de parasitas gastrintestinais em fezes de cães e gatos, Curitiba-PR. Revista Acadêmica Ciência Animal, 3(4), 31-34. Retrieved in 2019, August 8, from https:// periodicos.pucpr.br/index.php/cienciaanimal/article/view/9207/8859

Valiei, K., \& Beheshti, R. (2011). Double intussusception in dog. Asian Journal of Animal and Veterinary Advances, 6(9), 971-976. http://dx.doi.org/10.3923/ajava.2011.971.976. 